J. Amer. Soc. Hort. Sci. 115(2):319-323. 1990.

\title{
Coinoculation Effects of the Pathogens Causing Common Bacterial Blight, Rust, and Bean Common Mosaic in Phaseolus vulgaris
}

\author{
H.Z. Zaiter, D.P. Coyne, and J.R. Steadman \\ Departments of Horticulture and Plant Pathology, University of Nebraska, Lincoln, NE 68583 \\ Additional index words. interactions, Xanthomonas campestris pv. phaseoli, Uromyces appendiculatus, Mamor phaseoli, \\ dry bean

\begin{abstract}
Ten dry bean (Phaseolus vulgaris L.) cultivars/lines with differential reactions to rust were used in growth chamber experiments to determine rust [Uromyces appendiculatus (Pers.) Unger var. appendiculutus, (U a)], and common bacterial blight Xanthomonas campestris pv. phaseoli (E.F. Sm.) Dews. (X $\mathrm{c}$ p)] reactions on leaves when coinoculated with both pathogens. The $X c p-U$ a necrosis symptoms were very different from those caused by $X c p$ alone. Depending on the level of host susceptibility to rust, the $X c p$ reaction remained confined within the rust pustule or spread beyond the pustule area, causing a necrosis of the entire leaf. Prior infection of bean seedlings with bean common mosaic virus (BCMV), NY-15 strain, reduced rust pustule size, but did not affect the reaction to $X c$ $p$. Screening with $X$ c $p$ and BCMV can be done at the same time during the early vegetative stage, but the interactions of $U a$ with $X$ c $p$ and of BCMV with $U a$ need to be considered in screening for resistance.
\end{abstract}

Rust, common bacterial blight $(X c p)$, and bean common mosaic virus (BCMV) often occur together and affect dry bean production worldwide (Ballantine, 1978; Hampton, 1975; Yoshi, 1980). Resistances to $X c p$, rust, and BCMV need to be combined in cultivars for use in many bean production areas of the world.

The susceptibility of a plant to a pathogen is sometimes altered if the plant is already invaded by another pathogen (Carter, 1956; Dillon-Weston, 1927; Finke et al., 1986; Smith, 1951; Stall, 1955; Yarwood, 1950, 1969). The joint inoculation of $U$ $a$ and $X c p$ was studied by Finke et al. (1986) and DeFaria and Hagedorn (1986) on separate trifoliolate leaves; no antagonistic or synergistic interaction was found between the two pathogens. Virus infection often increases host susceptibility to necrotrophic foliar fungal pathogens (Beniwal and Gudauskas, 1974;

Received for publication 27 Feb. 1989. Published as Paper no. 8856, Journal Series, Nebraska Agricultural Research Division. Research was conducted under Title XII Bean/Cowpea CRSP Project-Univ. of Nebraska and Dominican Republic under AID Contract no. DAN-1310-G-SS-6008-00 and also under Projects no. 20-036 and 20-042. The cost of publishing this paper was defrayed in part by the payment of page charges. Under postal regulations, this paper therefore must be hereby marked advertisement solely to indicate this fact.
Bente, 1973). Studies on interactions between viruses and rusts of graminaceous hosts have shown that virus infection may decrease pustule density (Latch and Potter, 1977; Potter, 1982). However, some viruses have no effect on rust development. Raju et al. (1969) showed that development of Puccinia recondita sp. tritici was similar on virus-free and brome mosaic virusinfected wheat, but that rust developed more profusely on plants infected with wheat streak mosaic virus than on virus-free plants (Raju et al., 1969). We could not find reports of similar studies of rust development on dry bean in the presence or absence of a systemic virus. Hedges (1944, 1946a, 1946b) and Panzer and Nickeson (1959) studied the BCMV-bacterium effects on disease severity of $P$. vulgaris under field conditions. A synergistic effect of the two pathogens was noted only late in the growing season.

The objectives of this research were to determine the effect of prior inoculation of beans with the pathogens causing rust and BCMV on the reaction of the pathogens causing common blight and rust or common blight, respectively. This technique should be of importance to evaluate beans for multiple disease reaction, especially in tropical areas of the world where those diseases occur simultaneously. It can also be used in situations 
Table 1. Disease ratings of dry bean cultivars/lines inoculated singly and coinoculated with the pathogens causing rust (U a; Uromyces appendiculatus var. appendiculatus) and common blight (Xc p; Xanthomonas campestris pv phaseoli).

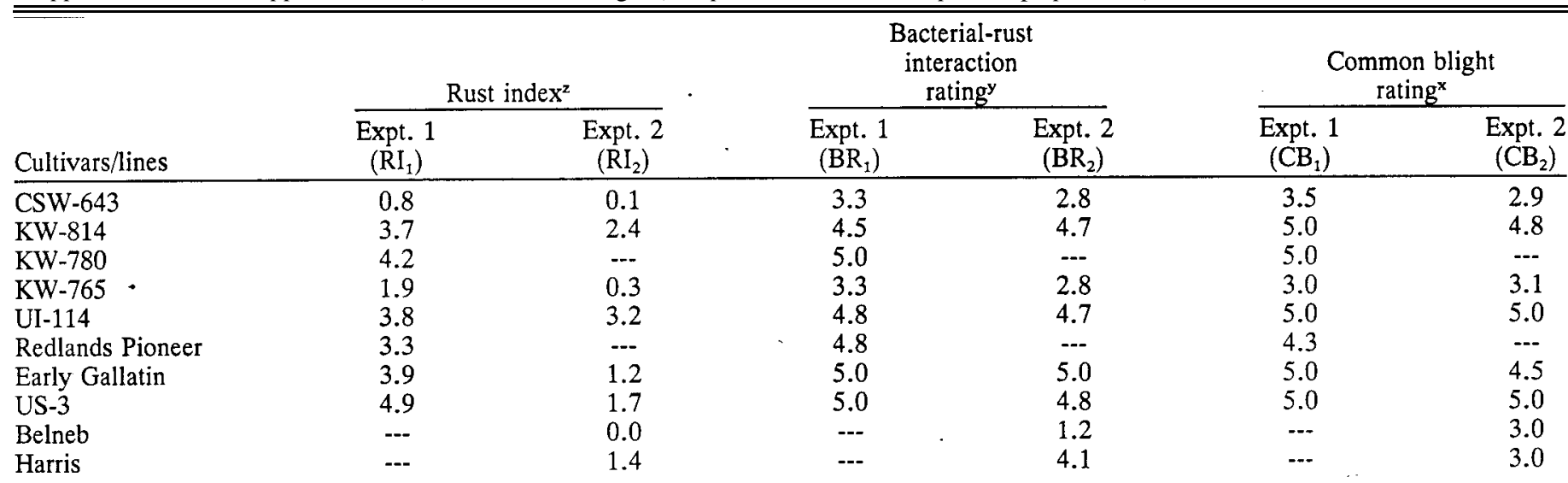

Simple correlation between $\mathrm{RI}_{1}$ and $\mathrm{RI}_{2}=+0.71^{*}, \mathrm{BR}_{1}$ and $\mathrm{BR}_{2}=+0.99^{*}$, and $\mathrm{CB}_{1}$ and $\mathrm{CB}_{2}=+0.95^{*}$.

Rank correlation between $\mathrm{RI}_{1}$ and $\mathrm{RI}_{2}=+0.54^{*}, \mathrm{BR}_{1}$ and $\mathrm{BR}_{2}=+0.97^{*}$, and $\mathrm{CB}_{1}$ and $\mathrm{CB}_{2}=+0.79^{*}$.

$\mathrm{LSD}_{0.05}$ value to compare means for the same inoculation treatment for different cultivars/lines was 0.60 in both experiments.

${ }^{2}$ Rust index $=$ Pustule grade $\times$ infection intensity.

yacterial-rust disease rating classes were: 1) no visible symptoms; 2) lustrous black flecks; 3) water-soaking and necrosis within the rust lesion; 4) water-soaking and necrosis surrounding rust lesion; 5) water-soaking and necrosis over the leaf surface.

${ }^{x}$ Common blight disease rating classes were: 1) no visible symptom; 2) small lesions on $1 \%$ to $5 \%$ of inoculated area; 3) lesions of moderate size on $6 \%$ to $25 \%$ of inoculated area; 4) lesions of varying size on $26 \%$ to $50 \%$ of inoculated area; 5 ) lesions of varying size on $>50 \%$ of inoculated area.

*Significant at $P=0.05$.

of limited space, or to obtain faster results of bean germplasm evaluation for resistance to more than one of the pathogens.

\section{Materials and Methods}

Coinoculation of $U$ a and $X c$ p. Bean plants were grown in a growth chamber (Expt. 1) to test the effect of the presence of $U a$ on the "reaction of $X c p$ in two experiments. A split-plot design was used with cultivars as main plots, replicated four times, and inoculation treatments as subplots. Eight bean cultivars, ranging from highly susceptible to moderately susceptible to a North Platte, Neb., $U a$ isolate (US-NP-10-1), were used. Subplot treatments were as follows: 1) The abaxial surfaces of fully unfolded primary leaves of bean seedlings were inoculated with a water suspension of urediniospores $\left(10^{5}\right.$ spores/ ml) using a modified crown sprayer 7 to 12 days after seeding (Fisher Scientific Co.). The plants were incubated in a humidity chamber for $18 \mathrm{hr}$ (overnight), then moved to a growth chamber at 20 to $25 \mathrm{C}$. 2) The fully unfolded primary leaves were inoculated with five isolates of $X c p$ from various geographic regions combined in a bacterial suspension $\left(10^{7} \mathrm{cfu} / \mathrm{ml}\right)$ sprayed to run off on the leaves. The five $X c p$ isolates used were: CBP 184 (Colombia), DRL-827 (Dominican Republic), T-45 br (Puerto Rico), EK-11, and LB-2 (Nebraska). Differences in levels of virulence of these isolates have been reported (Zaiter et al., 1989). 3) The abaxial surfaces of fully unfolded primary leaves were inoculated with $U a$ urediniospores as described previously. The leaves were then sprayed ( 2 weeks after this inoculation) to run off with $X c p$ isolates when uredinia had erupted. No water soaking or wounding of the leaves occurred. Disease ratings for $U a$ and $X c p$ were made 10 days after inoculation with $X c p$ (Table 1).

Six of the eight bean cultivars used in Expt. 1, along with 'Belneb-1' (rust-resistant) and 'Harris' (rust-susceptible) culti-
Table 2. Mean rust pustule diameter and disease reaction on dry bean cultivars/lines inoculated singly or coinoculated with the pathogens causing rust ( $U$ a; Uromyces appendiculatus var. appendiculatus) and bean common mosaic virus (BCMV).

\begin{tabular}{|c|c|c|c|c|c|}
\hline \multirow[b]{3}{*}{ Cultivars/lines } & \multicolumn{4}{|c|}{ Type of plant ${ }^{2}$} & \multirow[b]{3}{*}{$\begin{array}{r}\text { BCMV } \\
\text { reaction }^{y}\end{array}$} \\
\hline & \multicolumn{2}{|c|}{ Control } & \multicolumn{2}{|c|}{ Infected } & \\
\hline & $\begin{array}{l}\text { Expt. 1 I } \\
\mathrm{s} \quad\left(\mathrm{RVF}_{1}\right)\end{array}$ & $\begin{array}{l}\text { Expt. } 21 \\
\left(\mathrm{RVF}_{2}\right)\end{array}$ & $\begin{array}{l}\text { Expt. } 1 \\
\left(\mathrm{RVI}_{1}\right)\end{array}$ & $\begin{array}{l}\text { Expt. } 2 \\
\left(\mathrm{RVI}_{2}\right)\end{array}$ & \\
\hline & & $m m$ & & & \\
\hline UI-111 & 0.58 & 0.55 & 0.50 & 0.48 & S \\
\hline U1-114 & 0.55 & 0.55 & 0.40 & 0.40 & $\mathrm{R}$ \\
\hline $\mathrm{WM}_{1}-85-39$ & NF & I & I & I & $\mathrm{R}$ \\
\hline $\mathrm{WM}_{1}-85-43$ & $\mathrm{NF}$ & NF & NF & $\mathrm{NF}$ & S \\
\hline
\end{tabular}

Simple correlation between $\mathrm{RVF}_{1}$ and $\mathrm{RVF}_{2}=+0.99 *$ and $\mathrm{RVI}_{1}$ and $\mathrm{R} \mathrm{VI}_{2}=+0.99 *$.

$\mathrm{LSD}_{0.05}$ values to compare means for the same inoculation treatment for different cultivars/lines in Expt. $1=0.04$ and Expt. $2=0.06$. $\mathrm{LSD}_{0.05}$ values to compare mean differences between $\mathrm{RVF}_{1}$ and $\mathrm{RVI}_{1}$ treatments $=0.02$ and $\mathrm{RVF}_{2}$ and $\mathrm{RVI}_{2}$ treatments $=0.02$.

${ }^{\mathrm{z}} \mathrm{I}=$ immune, no necrosis or other evidence of infection; $\mathrm{NF}=$ necrotic flecking without spores.

${ }^{\mathrm{y}} \mathrm{R}=$ resistant; $\mathrm{S}=$ susceptible.

* Significant at $P=0.05$.

vars, were tested subsequently in Expt. 2 in a split-plot with six replicates (Table 1).

In both experiments, plants were grown in $15-\mathrm{cm}$ (1.8-liter) clay pots (two per pot) containing $5 \mathrm{~kg}$ (1.4 liter) of steampasteurized potting medium (equal parts of sand, Sharpsburg silty clay loam soil, vermiculite, and peatmoss). Air was maintained $\approx 23 \mathrm{C}$ during $10 / 14 \mathrm{hr}$ (light/dark) periods at a photosynthetic photon flux (PPF) of $340 \mu \mathrm{mol} \cdot \mathrm{s}^{-1} \cdot \mathrm{m}^{-2}$ at a plant height $110 \mathrm{~cm}$ below the light source. High-pressure sodium and metal halide lamps were used. 
Table 3. Common blight $(X c p)$ reaction on leaves of dry bean cultivars/lines inoculated with Xanthomonas campestris pv. phaseoli on bean common mosaic (BCMV) control plants and on BCMVinoculated plants.

\begin{tabular}{lccl}
\hline \hline Cultivars/lines & BCMV-control & BCMV-infected & $\begin{array}{c}\text { BCMV } \\
\text { reaction }\end{array}$ \\
\hline Sanilac & 98 & 100 & Susceptible \\
EP-1 & 39 & 43 & Resistant \\
WM $_{1}-85-57$ & 40 & 53 & Resistant \\
UI-114 & 100 & 100 & Resistant
\end{tabular}

$\mathrm{LSD}_{0.05}$ value to compare means for the same inoculation treatment for different cultivars/lines $=18$.

$\mathrm{LSD}_{0.05}$ value to compare means between different inoculation treatments $=8$

${ }^{2} X c p$ rating scale: $0 \%$ (no symptoms) to $100 \%$ necrosis of the leaf area inoculated with the multiple needle.

The pustule rating system described by Stavely (1984) was used (Table 2). Rust intensity (the percentage of leaf area with rust symptoms) was classified from $0 \%$ to $99 \%$ of the leaf area. A rust index, pustule grade $\mathrm{x}$ infection intensity, was used to evaluate the leaf rust disease reaction. The term "bacterial-rust necrosis" was used to describe the distinct bacterial/rust symptoms, and the ratings were based on the type of bacterial lesions surrounding the rust pustules (Table 1).

Coinoculation of $\mathrm{U}$ a and $B C M V$. Two separate experiments were conducted in growth chambers, replicated four times in each experiment. Bean plants were grown as in the $U a$ and $X$ $c p$ coinoculation study.

The BCMV (NY-15 strain) was maintained in the dry bean cultivar Sanilac. Inoculum was prepared by picking leaves of 2- to 6-week-old BCMV-diseased plants, grinding them in a mortar and pestle, diluting 1:5 with distilled water, and mixing with 500-mesh Carborundum powder.

The following four cultivars/lines comprised the main plots arranged in a randomized complete block design; 'UI 111' and $\mathrm{WM}_{1}-85-43$, both susceptible to BCMV (NY-15 strain), and 'UI-114' and $\mathrm{WM}_{1}-85-39$, both resistant to the same BCMV strain. Subplot treatments were as follows: 1) The abaxial surface of fully unfolded primary leaves of seedlings were inoculated with rust urediniospores (US-NP-10-1); 2) One-half- to three-fourths-expanded primary leaves were rubbed lightly with the BCMV inoculum by hand; and 3) One-half- to three-fourthsexpanded primary leaves were inoculated with BCMV and then the same primary leaves, when fully unfolded, were inoculated with rust urediniospores.

Disease ratings for virus and rust were made 14 days after the rust inoculation. The rust pustule rating system described by Stavely (1984) was used (Table 2).

Coinoculation of $\mathrm{X} \mathrm{c} \mathrm{p}$ and BCMV. Cultivars/lines comprised the main plots (four replications) in a randomized completeblock design with three inoculation treatments as subplots. The cultivars/lines included 'Sanilac' (susceptible to BCMV and X

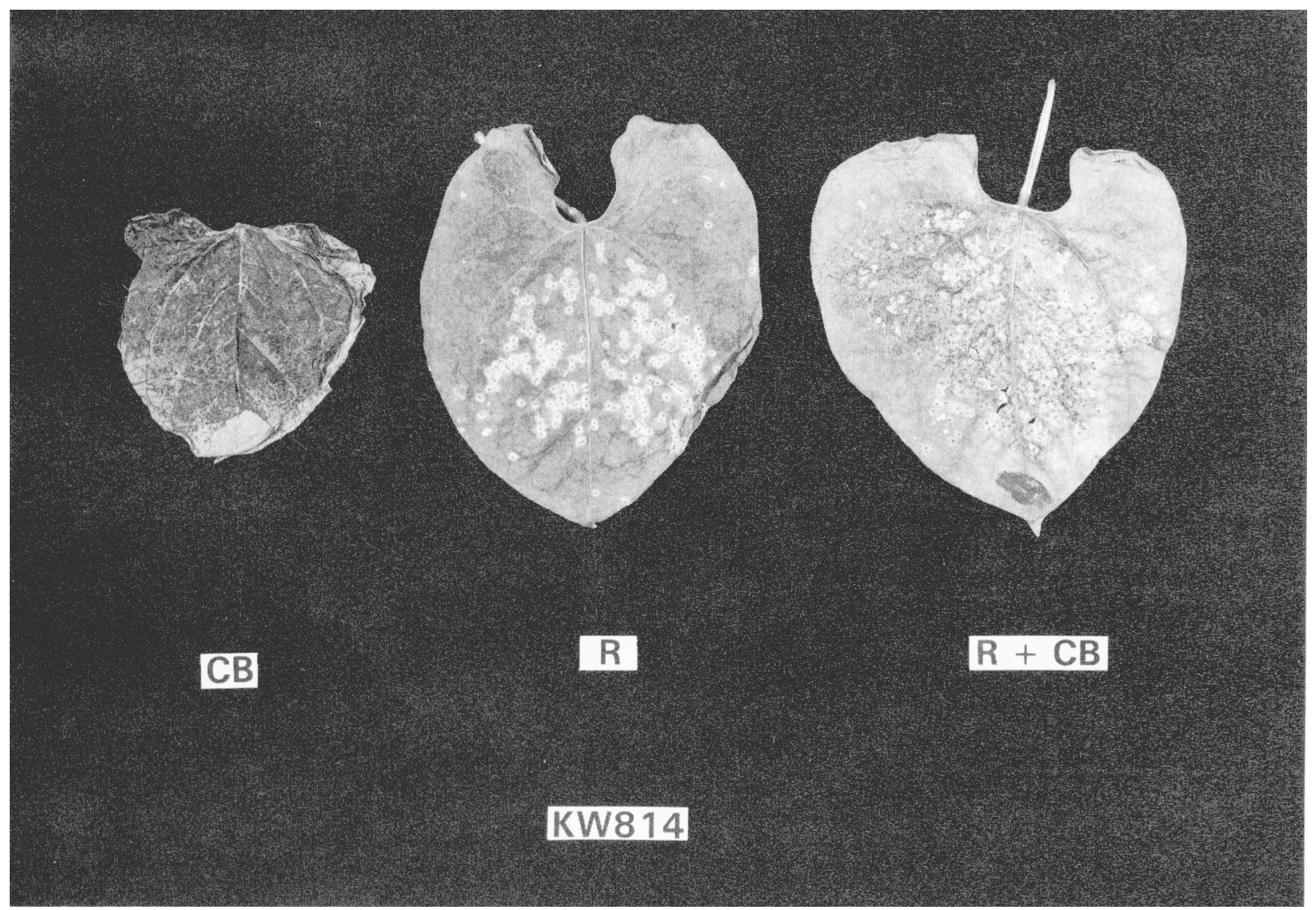

Fig. 1. Symptoms produced by single- and co-inoculation of Xanthomonas campestris pv. phaseoli (X c p) and Uromyces appendiculatus var. appendiculatus $(U a)$ on fully expanded primary leaves of dry bean cultivar KW-814. (left to right): Common blight symptoms-inoculation with $X c p$ alone; rust pustules-inoculation with $U a$ alone; bacterial-rust necrosis symptoms following co-inoculation. 


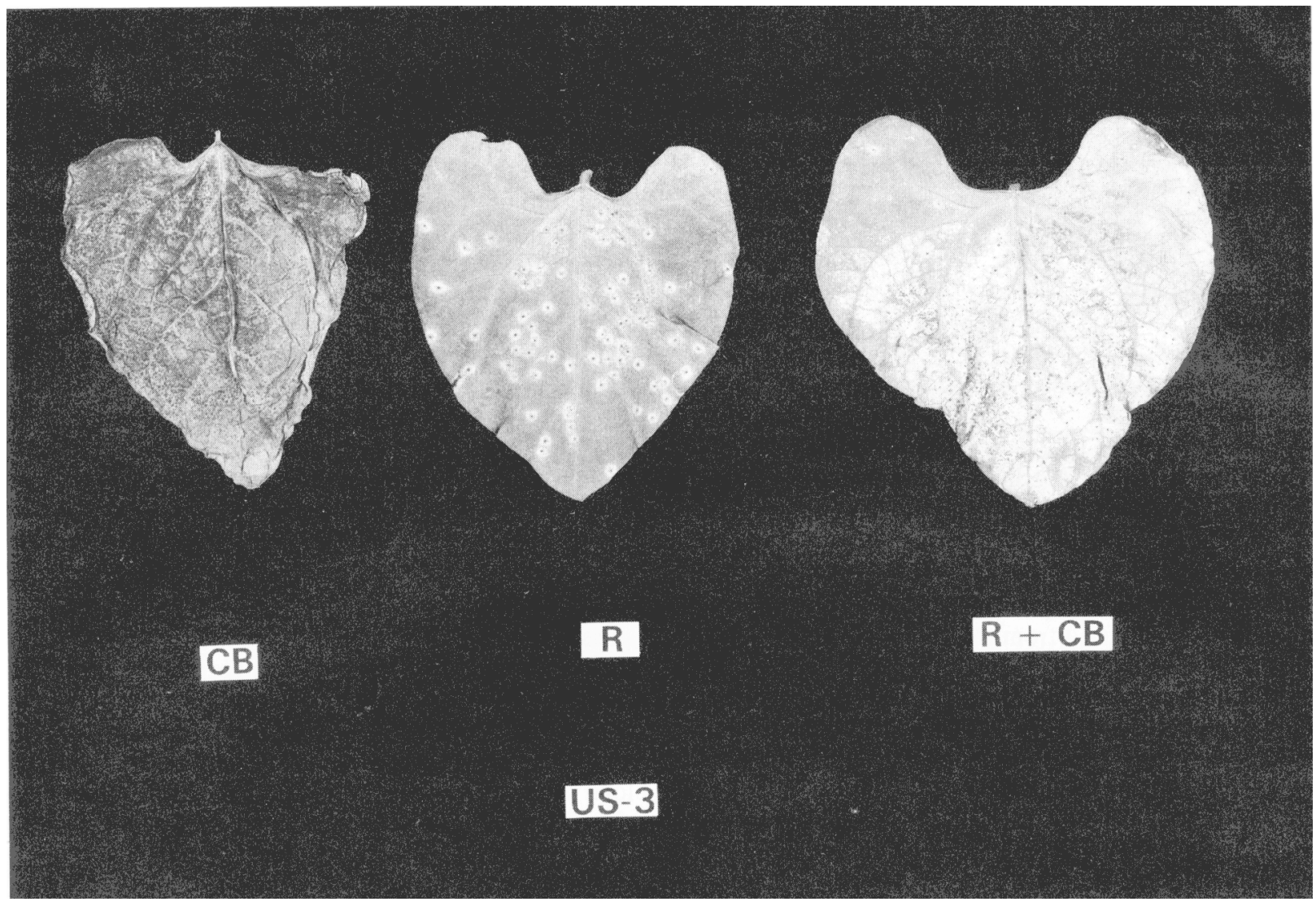

Fig. 2. Symptoms produced by single- and co-inoculation of Xanthomonas campestris pv phaseoli (X $c$ p) and Uromyces appendiculatus var. appendiculatus $(U a)$ on fully expanded primary leaves of dry bean cultivar US-3. (left to right): Common blight symptoms-inoculation with $X c p$ alone; rust pustules-inoculation with $U a$ alone; bacterial-rust necrosis symptoms following co-inoculation.

c p), EP-1 (resistant to BCMV and X c p), 'UI 114' (resistant to BCMV and susceptible to $X c p$ ), and $\mathrm{WM}_{1}-85-57$ (resistant to BCMV and $X c p$ ). Inoculation methods for the two pathogens were those described previously. Bean plants were grown as in the $U a$ and $\mathrm{X}$ c $p$ coinoculation study.

The three inoculation treatments were as follows: 1) Fully unfolded trifoliolate leaves of seedlings were inoculated with $\mathrm{X}$ c $p$; 2) One-half- to three-fourths-expanded primary leaves were inoculated with BCMV; and 3) One-half- to three-fourths-expanded primary leaves of seedlings were inoculated with BCMV (NY-15) and later the first trifoliolate leaves were inoculated with $\mathrm{X}$ c p.

Disease ratings for common blight and BCMV were made 12 days after inoculation (Table 3).

\section{Results and Discussion}

Coinoculation of $\mathrm{U}$ a and $\mathrm{X} \mathrm{c}$ p. Rust accentuated the damage caused to foliage by $X c p$ (Figs. 1 and 2). We suggest that when uredinia erupted, bacteria entered the wounded tissue and caused the necrotic lesions on the leaves. Depending on the level of host susceptibility, the bacterial lesions were confined within the rust lesions or extended over the entire leaf (Figs. 1 and 2). These bacterial-rust necrosis symptoms were very different from those caused by $X c p$ alone. The correlations between rust index and lesion size in bacterial-rust necrosis interactions were +0.93 and +0.78 in Expts. 1 and 2, respectively. Susceptibility to bacterial-rust necrosis was associated with the rust index and with susceptibility to $X c p$ (Table 1).
The correlations between results of all inoculation treatments in Expts. 1 and 2 were high, indicating repeatability (Table 1). The interaction of the $U a$ and $X c p$ would cause plant stress at least as great as either pathogen alone and could be additive on beans. This situation can arise in the tropics where plants are often first infected with $U a$ and then later with $\mathrm{X} \mathrm{c} p$.

Coinoculation of $U$ a and BCMV. Rust development was similar on control and virus-infected plants irrespective of the leaf surface inoculated (Table 2). Flecking occurred 8 days after 'inoculation. White pustules formed after 12 days and erupted 2 days later in both experiments. The correlations between the two experiments under BCMV-free and BCMV-infected plants were very high (Table 2 ).

Rust pustule size was smaller in BCMV-infected leaves than in control plants of 'UI-111' and 'UI-114', but there was no difference in the type of rust reaction for $\mathrm{WM}_{1}-85-43$ and $\mathrm{WM}_{1}-$ 85-39 in both experiments (Table 2). 'UI-114' and 'UI-111' remained rust-susceptible, and $\mathrm{WM}_{1}-85-43$ and $\mathrm{WM}_{1}-85-39$ remained rust-resistant in the presence of BCMV. Pustule intensity and spore production need to be studied in the future in healthy vs. virus-infected leaves because infection of faba bean (Vicia Faba L.) with bean yellow mosaic virus (BYMV) reduced rust pustule density of Uromyces viciae-fabae (Omar et al., 1986).

Because prior infection of dry beans by BCMV decreased host susceptibility to subsequent rust infection, but did not change a cultivar ranking from resistant to susceptible, or vice versa, this pathogen interaction should be considered in breeding pro- 
warns with the obiective of developing resistance to both pathogens. Multiple inoculation is therefore feasible and reliable, and can be used in screening for resistance, provided that control cultivars for each of the diseases are included in the tests.

Coinoculation of $X \mathrm{c} p$ and $B C M V$. There was no difference in symptoms induced by each pathogen when inoculated singly or co-inoculated on each of the four cultivars/lines (Table 3). Thus, presence of one pathogen did not affect the reaction to the other pathogen.

These results confirm those of Panzer and Nickeson (1959), where no synergistic or antagonistic effects were found at the early vegetative stage of beans in the field. However, they noted a synergistic effect of the two pathogens late in the growing season. The latter interaction, associated with maturity, was not investigated in this study.

Coinoculation with $X c p$ and BCMV in the seedling stage gave the same results as inoculating separately, and thus coinoculation can be effectively used by breeders in selecting for reaction to both pathogens.

\section{Literature Cited}

Ballantine, B.J. 1978. The genetic bases of resistance to rust, caused by Uromyces appendiculatus in beans (Phaseolus vulgaris). $\mathrm{PhD}$ Diss., Univ. of Sydney, Australia.

Beniwal, S.P.S. and R.T. Gudauskas. 1974. Maize dwarf mosaic virus increases susceptibility of sorghum and corn to Helminthosporium maydis race T. Phytopathology 64:11 97-1201.

Bente, M.K. 1973. Increased leaf exudation enhances curvularia leaf spot severity in virus-infected gladiolus. Phytopathology 63: 12021205.

Carter, H.P. 1956. Influence of disease on susceptibility of a plant to the same or a different plant pathogen. Ohio State Univ. Plant Pathol. Seminar Paper 15.

DeFaria, J.C. and D.J. Hagedorn. 1986. A multiple inoculation technique for selection of bean seedlings with resistance to three pathogens. Fitopat. Brasil. 11:535-542.

Dillon-Weston, W.A.R. 1927. The incidence and intensity of Puccinia glumarum Eriks. and Henn., on wheat infested and noninfested with tilletia tritici showing an apparent relationship between the susceptibility of wheat plants to yellow rust and to bunt. Ann. Applied Biol. 14:105-112.

Finke, M. L., D.P. Coyne, and J.R. Steadman. 1986. The inheritance and association of resistance to rust, common bacterial blight, plant habit and foliar abnormalities in Phaseolus vulgaris L. Euphvtica 35:969-982.

Hampton, R.O. 1975. The nature of bean yield reduction by bean yellow and bean common mosaic viruses. Phytopathology 65:13421346.

Hedges, F. 1944. Association of Xanthomonas phaseoli and the common bean mosaic virus, Marmor phaseoli: I. Effect on pathogenicity of the seedborne infective agents. Phytopathology 34:662-693.

Hedges, F. 1946a. Association of Xanthomonas phaseoli and the common bean mosaic virus, Marmor phaseoli: II. Dissociation studies of X. phaseoli. Phytopathology 36:589-612.

Hedges, F. 1946b. Association of Xanthomonas phaseoli and the common bean mosaic virus, Marmor phaseoli: III. The effect of varying amounts of nitrogen on pathogenicity. Phytopathology 36:613-623.

Latch, G.C.M. and L.R. Potter. 1977. Interaction between crown rust (Puccinia coronata) and two viruses of rye grass. Ann. App!ied Biol. 87:139-145.

Omar, S. A.M., K.W. Bailiss, G.P. Chapman, and J.W. Mansfield 1986. Effects of virus infection of faba bean on subsequent infection by Uromyces viciae-fabae. Plant Pathol. 35:535-543.

Panzer, J.D. and R.L. Nickeson. 1959. Delayed synergism of bacterial blight and bean mosaic on Phaseolus vulgaris L. Plant Dis. Rptr. 43:133-136.

Potter, L.R. 1982. Interaction between barley yellow dwarf virus and rust in wheat, barley and oats, and the effects on grain yield and quality. Ann. Applied Biol. 100:321-329.

Raju, D. G., W.H. Sill, and L.E. Browder. 1969. The combined effects of two viral diseases and leaf rust on wheat. Phytopathology 59:14881492.

Smith, K.M. 1951. Recent advances in the study of plant viruses. J. and A. Churchill, London.

Stall, R. 1955. Acquired immunity in plant virus diseases. Ohio State Univ. Plant Pathol. Seminar Paper 2. Columbus.

Stavely, J.R. 1984. Genetics of resistance of Uromyces phaseoli in the United States and rust resistance in beans. Plant Dis. 69:95-99.

Yarwood, C.E. 1950. Transmitted effects of bean powdery mildew and bean rust. Phytopathology 40:97.

Yarwood, C.E. 1969. Association of rust and halo blight on beans. Phytopathology 59:1302-1305.

Yoshi, K. 1980. Common and fuscous blight, p. 157-172. In: H.F. Schwartz and G.E. Galvez (eds.). Bean production problems. Centro Intl. Agr. Trop. (CIAT), Cali, Colombia.

Zaiter, H. Z., D.P. Coyne, A.K. Vidaver, and J.R. Steadman. 1989. Differential reaction of Tepary bean lines to Xanthomonas campestris pv. phaseoli. HortScience 24:134-137. 